proof read each issue and Sarah Froggatt has been a very encouraging Chair.

Finally, when I took over as Editor, Sweet \& Maxwell were the publishers. We moved to Cambridge University Press in 2004 and the team there have been a pleasure to work with. Sue Perkins has acted as Production Editor for the whole period and has offered a brilliant service. Ella Colvin was our first Publisher and both she and Rebecca O'Rourke have offered constant advice and encouragement. I will miss you all.

Christine Miskin

\title{
In Memoriam: Janet Schofield
}

Many members will have been deeply saddened to hear of Janet's untimely death on the $2 \mathrm{I}^{\text {st }}$ February $20 \mathrm{II}$. Janet was such a well known and deeply respected member of BIALL that we thought we would share some memories from colleagues and her staff at Thomas Eggar, where she worked for many years.

Janet worked with Thomas Eggar for over 20 years, starting with the firm in 1989. Originally a history graduate, Janet went on to qualify as a librarian before focussing her career on law librarianship and knowledge management. She is one of those individuals who have seen the development of law librarianship through an amazing period of transformation, both in resources and services offered and changes in technology. Janet was responsible for developing a library service from scratch. The partners at the firm remember her as moving the firm from having a pile of dusty books in an office to the development of a modern full-service KM department, employing a small and dedicated team which supported the expansion of the business during her 20 years there.

For the partners one thing that really stood out for them was her total commitment to service excellence. She was always ready to go the extra mile and is very fondly remembered by all for her commitment and care. She developed very strong friendships at work and is sorely missed by many.

Her team also remember her for her dedication and her sense of humour. Everyone remarked on the very long hours that Janet worked for the firm, but also commented on her style, grace and generosity. Janet was an excellent cook and liked to bring in a treat when her team were having a particularly hard time. She had a great passion for walking, for her garden, opera and for life in general.

Janet was very interested in extending and improving knowledge management within the firm. Both she and I worked together for a year on the Nottingham Law School Diploma in knowledge management. As anyone who has been on the course will know, this involved a lot of study and work at intensive weekend workshops. Throughout the year Janet worked incredibly hard but was always positive and upbeat during our workshop sessions. She became an integral part of

Janet Schofield her team and her sense of humour and tact were invaluable in getting everyone working together. What is absolutely amazing is that at the time Janet had already been suffering with the cancer that ultimately cut short her life, but never once let it interfere with her studies. I can remember being completely in awe of her determination to continue to enjoy life to the full and to make the absolute most of the time she spent studying.

Janet also played a very active part in BIALL over the years. Loyita Worley recalls with great fondness the time that they worked together:

"I can't remember how or when I met Janet - no doubt at a British and Irish Association of Law Librarians (BIALL) event. Having met, we hit it off immediately and found that we had a lot in common. We had both worked at our respective law firms for about the same length of time, I was born and raised in Worthing and Janet worked and lived in Chichester. We were both very enthusiastic about our work and shared the same sense of humour. We met from time to time at meetings and conferences and had regular phone calls regarding work issues. 
The 1998 BIALL Conference was to be held in Portsmouth and coincided with my year as Chair of the Association. In those days the Conference was entirely run by BIALL members and, when I knew that it was to be held on the south coast, I immediately thought of approaching Janet to be on the committee. When I asked her, she said that from the minute that she heard my name in connection with Portsmouth she was just waiting for my call!

Luckily for me she agreed to be the Local Conference Organiser and we worked together very closely over a two year period. Janet was thorough, practical and always reliable. We put many hours of work into the planning and organisation of what turned out to be a very successful conference. We had the odd potential disaster, but also had lots of fun and laughs along the way - she was great. Latterly, our paths crossed less frequently, but every time they did it was lovely to see her and we always caught up exactly where we had left off. I will miss her professionalism and friendship but will always remember her with a smile."

For everyone who met Janet at conferences over the years, who worked with her on committees, as part of the Law South library network and within Thomas Eggar, I am sure you will all join with me in giving thanks for having known Janet and pass on our deepest sympathies to her husband Mike, her family and friends.

Ann Hemming

\section{The Legal Profession in a Changing World}

\section{Guest Editorial}

The aim of this theme, entitled, The Legal Profession in a Changing World is to examine the sweeping changes being brought about by the Legal Services Act (LSA) 2007. Much of this change centres on alterations to the regulatory landscape for legal practitioners in England and Wales, including the introduction of Alternative Business Structures (ABSs). Other factors, including the new Bribery Act, extensive changes to legal aid, a new complaints against solicitors handling regime and the process of outsourcing legal services, will also have a significant impact on the legal profession over the next few years.

The intention of the Legal Services Act 2007 was to ensure that consumers received a professional service from those providing legal services, and to allow law firms to do new and better things for clients, by providing more flexibility and reducing bureaucracy. It is four years now since the publication of the Act and, by the time this issue is published, the new Solicitors Regulation Authority (SRA) Handbook will have been released and from the 6th of October 201I the new regulatory regime will finally come into force.

What will this new "outcomes focused regulation" look like? Bronwen Still explains this in much more detail in her article (see p 85) but essentially the idea is to provide a framework within which firms of all shapes and sizes can determine the approach to the compliant conduct of business which best suits their own business model, within parameters defined by the regulator. Rather than prescriptive Rules, the new approach will be based on a targeted, risk-based approach concentrating on the standards of service to consumers. The SRA Handbook sets out the ethical standards expected of individual solicitors and law firms and the outcomes they will be expected to achieve for their clients. It will be accessible free of charge on the SRA website and available in print from the Law Society.

The changes will affect barristers as well as solicitors and Baroness Deech, the Chair of the Bar Standards Board, considers the impact of the LSA 2007 on the regulation of the Bar (see $p 89$ ).

Complaints handling is another area of the regulatory regime that will change on the 6th of October. The Legal Ombudsman (LeO), set up last year, has taken over complaints handling from the Legal Complaints Service. Sara Meyer takes a look at the challenges in knowledge management that LeO faces (see $p$ 108).

Another key change for the profession is the introduction of Alternative Business Structures (ABSs) which describes a new type of law firm which will be permitted from October 201I. The SRA will license ABSs. These will include firms with more than 25 per cent non-lawyer managers; companies taken over by non-lawyer enterprises; companies floated on the stock exchange, or firms which provide both solicitor services and non-legal services. Dubbed "Tesco Law", the advent of ABSs is seen as "the legal profession's equivalent of the City's big bang" where, it is thought, new entrants to the legal profession will provide increased competition to established firms and therefore offer lower costs and greater efficiencies for the consumer. Clare Brown gives a good overview of the developments in the world of legal services operated via the internet on ( $\mathrm{P} \mid \mathrm{IO}$ ) and Nick JarrettKerr elaborates on what ABSs might mean for law firms in his article (see $p$ 82).

Further changes will come with the Bribery Act, which was published in April 2010 but implementation has been delayed due to the controversial nature of some of the requirements. In particular, the corporate offence 